\title{
KONSOLIDASI FOSIL MENGGUNAKAN RESIN ALAM
}

\author{
Leliek Agung Haldoko, Joni Setyawan, Sri Wahyuni, Arif Gunawan \\ Riyanto Prasetya Lambang \\ Balai Konservasi Borobudur \\ leliek_agung@yahoo.co.id
}

\begin{abstract}
ABSTRAK
Proses pemfosilan yang tidak berlangsung secara sempurna menyebabkan fosil dalam kondisi rapuh. Kondisi rapuh dikarenakan proses permineralisasi belum selesai sepenuhnya, sehingga terdapat bagian-bagian yang belum tergantikan oleh mineral. Untuk memperkuat ikatan material pada fosil yang rapuh diperlukan tindakan konsolidasi. Bahan konsolidan fosil yang selama ini digunakan adalah paraloid B72 dengan pelarut aceton yang terbatas dalam peredarannya.

Bahan yang diuji sebagai alternatif konsolidan fosil adalah gondorukem dan gelatin dengan konsentrasi $5 \%, 10 \%$ dan $15 \%$. Sebagai pembanding adalah bahan yang selama ini digunakan untuk konsolidasi fosil yaitu paraloid B72 4\%. Parameter pengujian yang digunakan antara lain uji SEM, uji kekerasan, uji kuat tekan, uji tetesan air, uji FTIR, uji daya tahan, pengamatan warna dan pengamatan pertumbuhan jamur.

Hasil pengujian yang telah dilakukan menunjukkan bahwa penggunaan gelatin 5\%, 10\% dan 15\% dapat menjadi alternatif pengganti paraloid B72 sebagai bahan konsolidasi fosil. Gelatin 5\% merupakan konsentrasi yang paling optimum untuk konsolidasi fosil karena penggunaan bahan akan lebih efisien. Bahan ini dapat mengisi pori-pori fosil dan meningkatkan kekerasan fosil. Nilai kuat tekan yang dihasilkan pada spesimen uji mencapai 423,02 N/cm2 lebih tinggi dari paraloid B72 4\% yang hanya 106,81 N/cm2. Penggunaan gelatin tidak merubah komposisi fosil dan memiliki daya tahan pada kondisi penyimpanan yang ekstrim. Penggunaan gelatin juga tidak merubah warna fosil dan aman dari pertumbuhan jamur ketika diaplikasikan ke fosil.
\end{abstract}

Kata Kunci: fosil, konsolidasi, gelatin, gondorukem, paraloid B72

\section{ABSTRACT}

Fossilization process that does not take perfectly causes fossil to be in a brittle condition. Brittle condition occurs because the permineralization process has not been completely completed, so there are parts that have not been replaced by minerals. To strengthen brittle fossils, consolidation treatment are needed. Material for fossil consolidation that has been used is paraloid B72 with acetone solvent, which is not easy to find everywhere

Materials tested for fossil consolidation were gondorukem and gelatin with concentration of $5 \%, 10 \%$ and $15 \%$. As a comparison, the material used for fossil consolidation is paraloid B72 $4 \%$. Test parameters used include SEM test, hardness test, compressive strength test, water drop test, FTIR test, aging test, color observation and fungal growth observation.

Test results have shown that the use of gelatin $5 \%, 10 \%$ and $15 \%$ can be an alternative to paraloid B72 as a fossil consolidation material. Gelatin 5\% is the optimum concentration for fossil consolidation because the use of materials will be more efficient. This material can fill the fossils pores and increase the hardness of the fossil. The resulting compressive strength value in the test specimen reached $423.02 \mathrm{~N} / \mathrm{cm} 2$, higher than $4 \%$ paraloid $\mathrm{B} 72$ which was only $106.81 \mathrm{~N} / \mathrm{cm} 2$. Gelatin does not change the composition of the fossil and resistant to extreme storage conditions. Gelatin also does not change the color of fossils and safe from fungal growth when applied to fossils.

Keywords: fossil, consolidation, gelatin, gondorukem, paraloid B72 


\section{PENDAHULUAN}

Fosil adalah sisa tulang belulang atau sisa tumbuhan zaman purba yang telah membatu dan tertanam di bawah lapisan tanah (Kamus Besar Bahasa Indonesia, 2005). Proses pemfosilan tidak selalu berlangsung secara sempurna. Hal ini mengakibatkan fosil rentan mengalami kerusakan seperti rapuh, patah maupun retak. Kondisi rapuh disebabkan karena proses permineralisasi belum selesai sepenuhnya, sehingga terdapat bagian-bagian yang belum tergantikan oleh mineral yang pada akhirnya akan menyebabkan kerapuhan. Oleh karena itu diperlukan tindakan untuk menangani permasalahan fosil yang rapuh yaitu dengan melakukan konsolidasi. Konsolidasi yang dilakukan merupakan upaya untuk memperkuat ikatan material pada fosil yang rapuh dengan memasukkan bahan melalui pori-pori fosil.

Balai Konservasi Borobudur sebagai UPT yang salah satu fungsinya adalah melakukan pengembangan metode dan teknik konservasi memandang perlu untuk mengembangkan metode untuk konsolidasi fosil sebagai alternatif untuk bahan konsolidan yang selama ini telah digunakan yaitu Paraloid B72. Bahan ini banyak dipakai karena dapat digunakan untuk mengkonsolidasi fosil tanpa perlu memilah komposisi fosilnya (dipakai untuk segala jenis komposisi fosil). Hal ini penting karena komposisi fosil yang satu dengan fosil yang lain bisa sangat beragam. Faktor penyebabnya antara lain adalah jenis tanah yang menguburnya maupun seberapa jauh tingkat fosilisasinya.

Paraloid B72 telah banyak dipakai di berbagai negara untuk konsolidasi fosil karena terbukti efektif. Akan tetapi karena merupakan bahan kimia, Paraloid B72 terbatas dalam peredarannya sehingga tidak di setiap daerah mudah untuk didapatkan. Karena itu pada tahun 2019 Balai Konservasi Borobudur mengadakan Kajian Konsolidasi Fosil Menggunakan Resin Alam. Resin alam yang akan digunakan adalah gondorukem dan gelatin. Dipilihnya gondorukem karena mempunyai sifat yang mirip dengan Paraloid 72, antara lain berbentuk padatan/kristal, larut sempurna dalam pelarut organik (berbasis minyak) dan mengeras kembali setelah pelarut menguap sehingga berpotensi dapat dipakai untuk konsolidasi fosil rapuh yang dalam kondisi kering. Sedangkan dipilihnya gelatin karena bahan ini dapat larut sempurna dalam air sehingga berpotensi dapat dipakai untuk konsolidasi fosil rapuh yang dalam kondisi basah maupun kering. Kedua bahan ini juga mewakili 2 basis bahan yang berbeda. Gondorukem mewakili bahan berbasis tumbuhan karena berasal dari getah pohon pinus sedangkan gelatin mewakili bahan berbasis hewani karena berasal dari ekstrak protein (kolagen) dari kulit dan tulang binatang. Selain itu kedua bahan ini sangat mudah didapatkan di pasaran dan harganya pun murah.

\section{METODE}

\section{a. Bahan}

Bahan yang digunakan adalah gondorukem, gelatin, paraloid B72 (teknis), tiner (teknis), etanol (teknis) dan air

\section{b. Cara Kerja}

\section{1) Pembuatan Bahan Konsolidan a) Gelatin :}

Gelatin akan mengembang dalam air dingin dan larut dalam air panas. Karena itu agar gelatin dapat larut sempurna dalam air dapat dilakukan dalam 2 tahap yaitu pertama gelatin dicampurkan ke dalam air dingin (air es) sampai $1 / 2$ bagian larutan dan ditunggu kurang lebih 5 menit (atau sampai membentuk seperti gel). Setelah itu langsung dicampurkan dengan air panas dan diaduk sehingga gelatin akan larut sempurna. Konsetrasi larutan gelatin yang digunakan adalah 5\%, 10\% dan $15 \%$. 


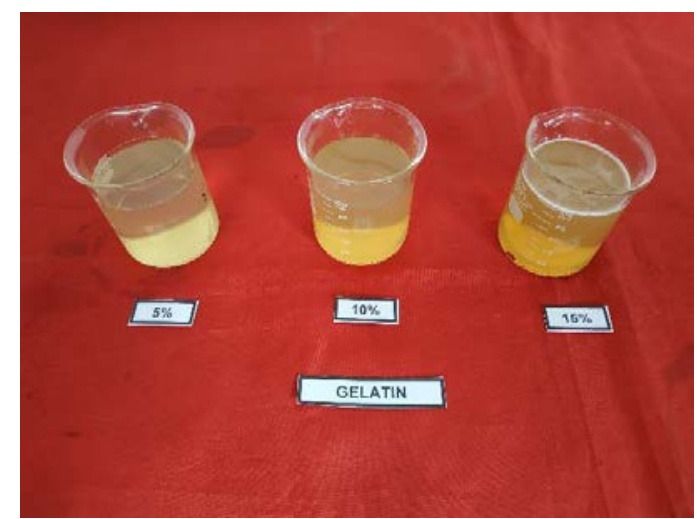

Gambar 1. Larutan gelatin 5\%, 10\% dan 15\%

\section{b) Gondorukem :}

Pelarut yang digunakan untuk membuat larutan gondodrukem adalah campuran thinner dan etanol. Pelarutan dilakukan dengan cara gondorukem dicampurkan dalam thinner sampai $1 / 5$ bagian larutan lalu diaduk dengan pengaduk kaca sampai tercampur sempurna. Setelah itu baru ditambahkan etanol sampai dengan tanda batas. Pada penelitian ini digunakan larutan gondorukem dengan konsentrasi 5\%, 10\% dan $15 \%$.

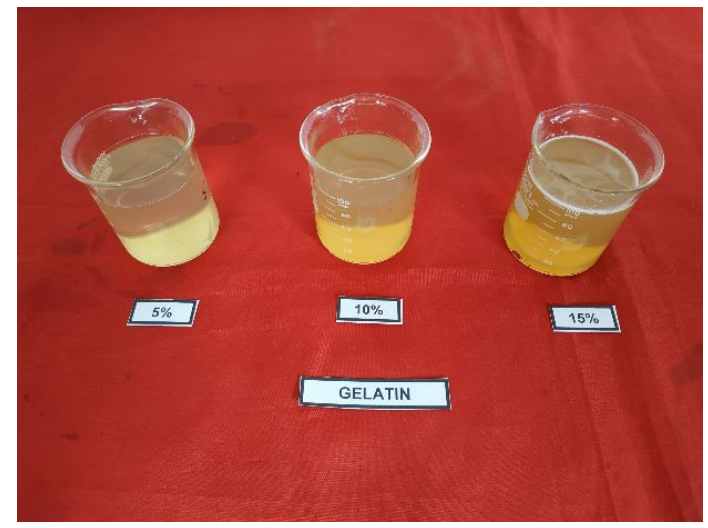

Gambar 2. Larutan gondorukem 5\%, 10\% dan 15\%

\section{c) Paraloid B72}

Konsentrasi larutan Paraloid B72 yang dipakai adalah $4 \%$ (dalam pelarut aceton) sesuai dengan konsentrasi maksimum yang telah dipakai di BPSMP Sangiran.

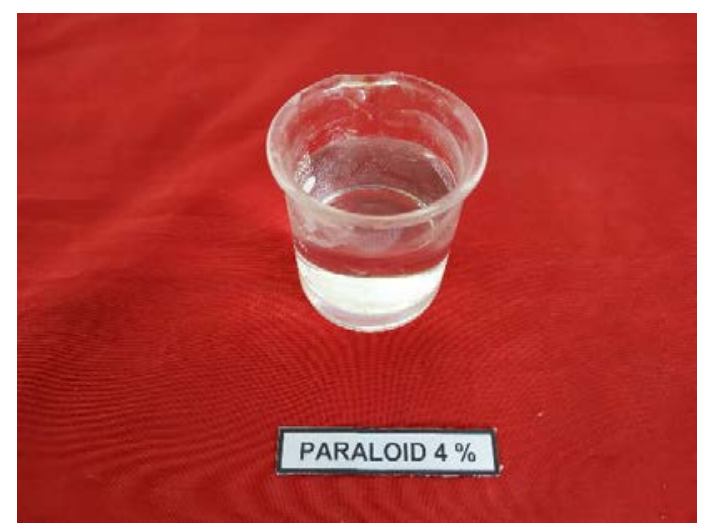

Gambar 3. Larutan paraloid B72 4\% 


\section{2) Preparasi Spesimen Uji}

\section{a) Spesimen fragmen fosil asli}

- Untuk uji kekerasan

Fragmen fosil dipotong menjadi 7 spesimen sesuai dengan jumlah konsolidan yang dipakai. Kemudian dilakukan pengukuran kekerasan menggunakan alat Ultrasonic Hardness Tester. Selanjutnya 7 spesimen fosil diberi perlakuan dengan direndam dalam bahan konsolidan selama 24 jam kemudian diangkat dan didiamkan sampai kering sempurna. Setelah spesimen uji kering sempurna kemudian kembali dilakukan pengujian kekerasan.

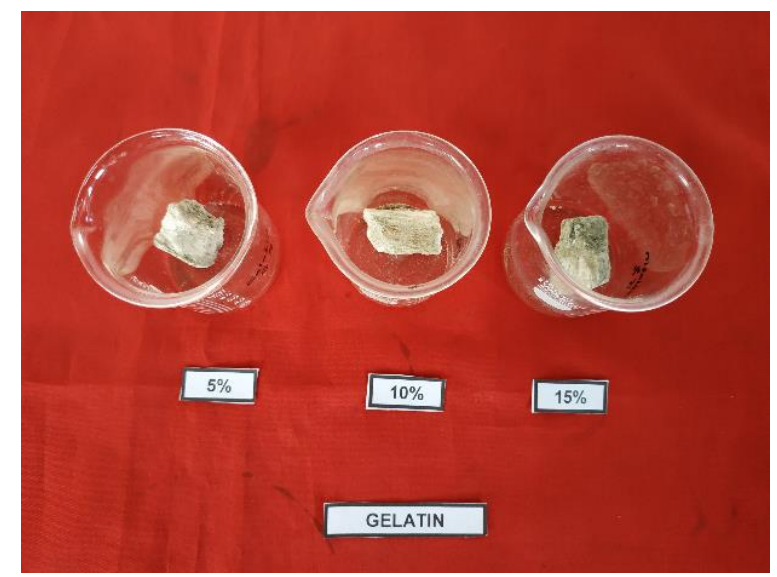

Gambar 4. Spesimen fragmen fosil untuk uji kekerasan

\section{- Untuk uji SEM}

Fragmen fosil dipotong menjadi 8 spesimen kecil yaitu 7 spesimen sesuai dengan jumlah konsolidan yang dipakai dan 1 spesimen untuk kontrol. Selanjutnya 7 spesimen fosil diberi perlakuan dengan direndam dalam masing-masing bahan konsolidan selama 24 jam kemudian diangkat dan didiamkan sampai kering sempurna. Kemudian pada spesimen yang telah kering dan spesimen kontrol dilakukan pengujian menggunakan SEM untuk.

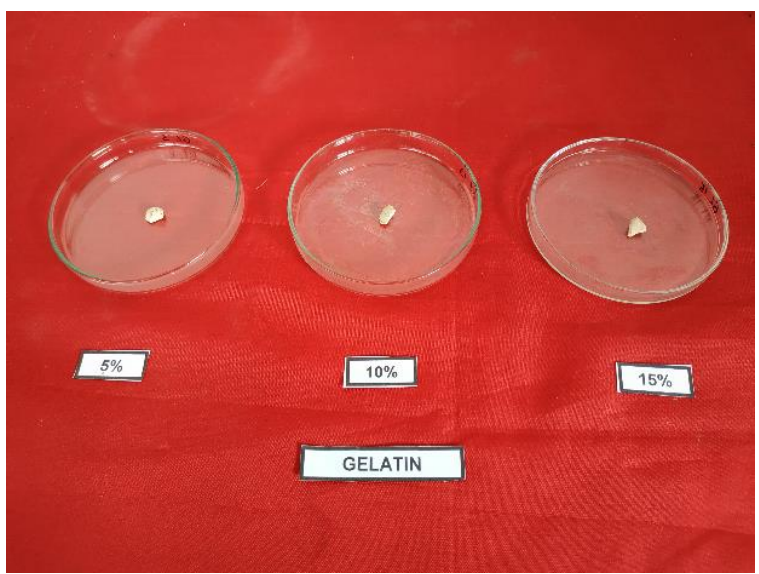

Gambar 5. Spesimen fragmen fosil untuk uji SEM 


\section{b) Spesimen fosil dibuat bubuk}

Fosil digerus menjadi bentuk bubukan. Bubukan fosil kemudian disaring menjadi 2 macam ukuran masing-masing dengan ukuran 250-500 $\mu \mathrm{m}$ dan kurang dari $250 \mu \mathrm{m}$. Selanjutnya bubukan fosil yang digunakan untuk membuat spesimen uji adalah campuran 1 bagian bubukan fosil ukuran 250-500 $\mu \mathrm{m}$ dan 2 bagian bubukan fosil dengan ukuran kurang dari $250 \mu \mathrm{m}$. Kemudian bubukan fosil dicampurkan dengan masing-masing bahan konsolidan dengan perbandingan 2 : 1 (2 bagian bubukan fosil dan 1 bagian konsolidan). Setelah tercampur sempurna kemudian dicetak dalam cetakan berbentuk silinder kemudian didiamkan sampai kering sempurna. Cetakan yang dipakai ada 2 macam ukuran yaitu dengan diameter $7 \mathrm{~mm}$ dan tinggi $14 \mathrm{~mm}$ untuk pengujian kuat tekan, serta diameter $12 \mathrm{~mm}$ dan tinggi $10 \mathrm{~mm}$ untuk uji tetesan air (water drop absorbtion), FTIR dan uji daya tahan (aging test), pengamatan warna dan pengamatan pertumbuhan jamur.

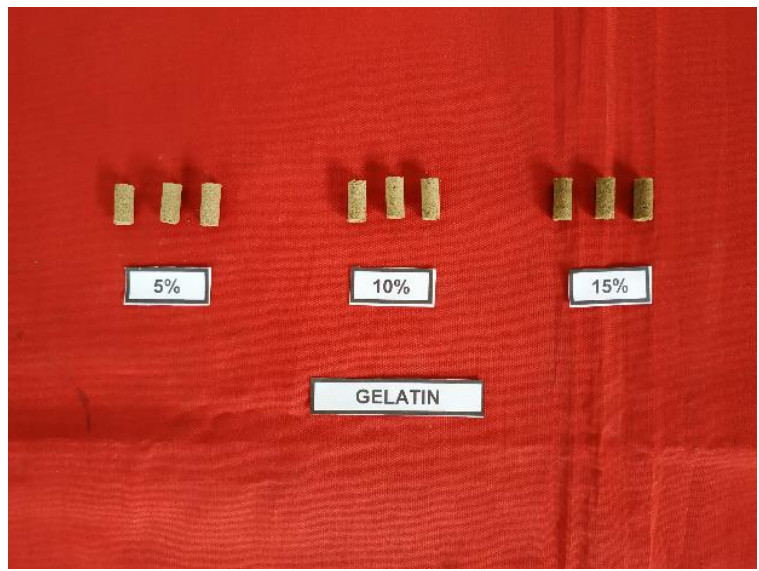

Gambar 6. Spesimen uji untuk pengujian kuat tekan

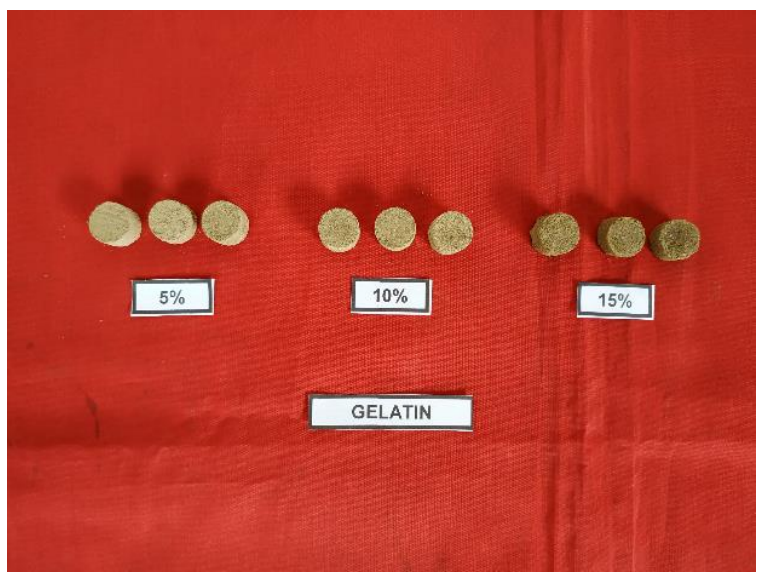

Gambar 7. Spesimen uji untuk pengujian water drop absorbtion, FTIR dan aging test,

\section{3) Pengujian karakteristik sampel uji}

\section{a) Uji Scanning Electron Microscope (SEM)}

Uji SEM dilakukan untuk mengamati struktur permukaan fosil. Dari analisis ini nantinya antara dibandingkan antara struktur permukaan fosil yang rapuh (belum dikonsolidasi) dan fosil yang telah dikonsolidasi. Analisis SEM akan dilakukan dengan alat SEM di Balai Konservasi Borobudur. 


\section{b) Uji kekerasan}

Uji kekerasan dilakukan melihat sejauh mana aplikasi konsolidan dapat meningkatkan nilai kekerasan fosil. Uji kekerasan dilakukan dengan alat Ultrasonic Hardness Tester di Balai Konservasi Borobudur.

\section{c) Uji kuat tekan}

Uji kuat tekan dilakukan untuk mengetahui kekuatan material dalam menahan beban per satuan luas, sehingga akan terlihat kekuatan material setelah dilakukan konsolidasi. Uji kuat tekan dilakukan di Laboratorium Bahan Teknik, Departemen Teknik Mesin dan Industri, Fakultas Teknik UGM.

$$
\mathrm{C}=\frac{\mathrm{P}}{\mathrm{A}}
$$

Keterangan :

$\mathrm{C} \quad=$ kuat tekan $(\mathrm{kg} / \mathrm{cm} 2)$

$\mathrm{P} \quad=$ beban $(\mathrm{kg})$

A $\quad=$ luas permukaan bidang uji $(\mathrm{cm} 2)$

d) Uji tetesan air (water drop absorbtion)

Uji tetesan air dilakukan dengan meneteskan air pada permukaan sampel uji untuk melihat apakah sampel uji yang telah dikonsolidasi dapat menyerap air atau tidak, sehingga akan terlihat apakah pori-pori permukaan spesimen uji dalam kondisi terbuka atau tertutup setelah dilakukan konsolidasi.

\section{e) Uji FTIR}

Fourier Transformed Infrared (FTIR) merupakan salah satu alat atau instrument yang dapat digunakan untuk mendeteksi gugus fungsi, mengidentifikasi senyawa dan menganalisis campuran dari sampel yang diuji. Analisis ini dilakukan dengan Spektrofotometer FTIR yang merupakan alat yang dapat digunakan untuk identifikasi senyawa, khususnya senyawa organik, baik secara kualitatif maupun kuantitatif. Analisis FTIR dilakukan di Laboratorium Kimia Organik, Departemen Kimia, Fakultas MIPA UGM.

\section{f) Uji daya tahan (aging test)}

Uji daya tahan (aging test) dilakukan untuk melihat daya tahan sampel pada kondisi yang diekstrimkan dari kondisi penyimpanan biasanya. Pada pengukuran temperatur dan kelembaban pada ruang pamer di BPSMP Sangiran didapatkan hasil temperatur maksimum $29,7^{\circ} \mathrm{C}$ dan temperatur minimum $23,4^{\circ} \mathrm{C}$ serta kelembaban maksimum $71,2 \%$ dan kelembaban minimum 54,0\%. Sedangkan Pada pengukuran temperatur dan kelembaban pada ruang penyimpanan fosil di BPSMP Sangiran didapatkan hasil temperatur maksimum $27,9^{\circ} \mathrm{C}$ dan temperatur minimum $23,6^{\circ} \mathrm{C}$ serta kelembaban maksimum 72,7\% dan kelembaban minimum 57,7\%. Oleh karena itu untuk pengujian daya tahan dilakukan pada kondisi temperatur dan kelembaban yang diekstrimkan yaitu sampel yang telah dikonsolidasi diberi perlakuan pada kondisi :

a) Kelembaban $90 \%$ dalam inkubator

b) Temperatur $50^{\circ} \mathrm{C}$ dalam oven

Setiap perlakuan dilakukan selama 24 jam dengan total selama 10 siklus. Nantinya akan dilihat kondisi sampel setelah dilakukan pengujian apakah mengalami kerusakan atau tidak. 


\section{g) Pengamatan warna}

Pengamatan warna dilakukan untuk melihat ada atau tidaknya perubahan warna fosil sebelum dan sesudah dilakukan konsolidasi dengan berbagai macam bahan konsolidan. Penggunaan bahan konsolidan tentunya diharapkan tidak sampai merubah warna fosil. Pengamatan warna ini dilakukan dengan alat bantu Munsell Soil Color Book.

\section{h) Pengamatan pertumbuhan jamur}

Pengamatan pertumbuhan jamur pada spesimen uji yang telah dikonsolidasi dilakukan secara visual untuk melihat ada/tidaknya jamur yang tumbuh pada permukaan fosil. Hal ini perlu dilakukan karena bahan yang diuji untuk konsolidasi fosil salah satunya adalah gelatin yang berasal dari protein dimungkinkan bisa ditumbuhi jamur. Pengamatan pertumbuhan jamur dilakukan dengan alat bantu mikroskop.

Data hasil pengujian yang telah dilakukan selanjutnya dianalisis sesuai dengan parameter yang diuji. Hasil pengujian bahan konsolidan fosil yaitu gelatin 5\%, 10\% dan $15 \%$ serta gondorukem 5\%, $10 \%$ dan $15 \%$ selanjutnya dibandingkan kontrol yaitu paraloid B72 4\%. Parameter pengujian yang dilakukan komparasi antar bahan meliputi uji SEM, uji kekerasan, uji kuat tekan, uji tetesan air, uji FTIR, uji daya tahan, pengamatan warna dan pengamatan pertumbuhan jamur. Hasilnya akan diperoleh bahan dengan konsentrasi optimum yang dapat dipakai untuk konsolidasi fosil sebagai alternatif bahan pengganti paraloid B72.

\section{HASIL DAN PEMBAHASAN \\ 1. Uji SEM}

Tabel 1. Foto SEM fosil dalam perbesaran 500 kali

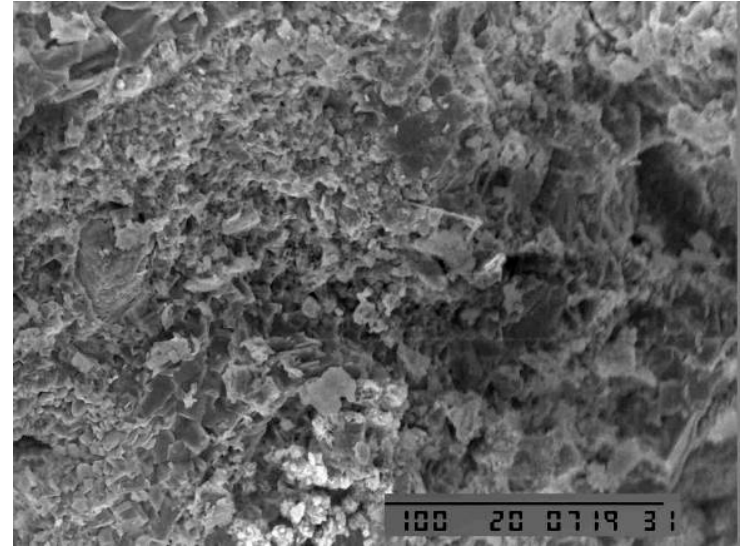

Tanpa perlakuan dengan bahan konsolidan

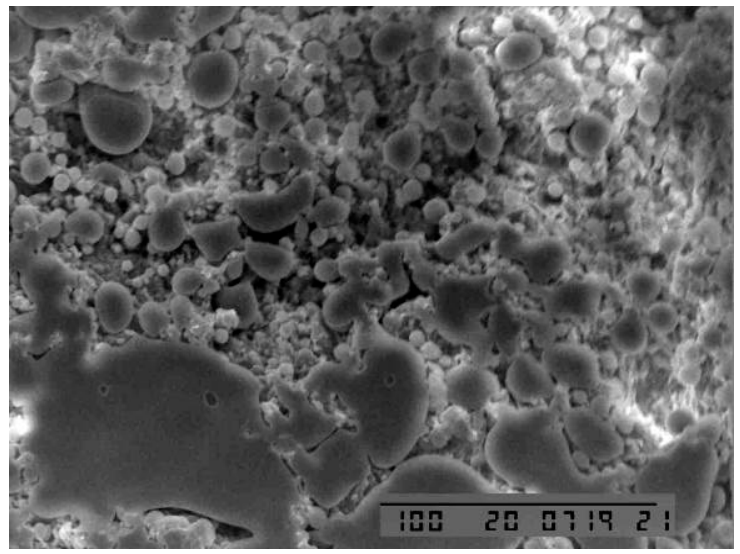

Aplikasi gondorukem $5 \%$ 


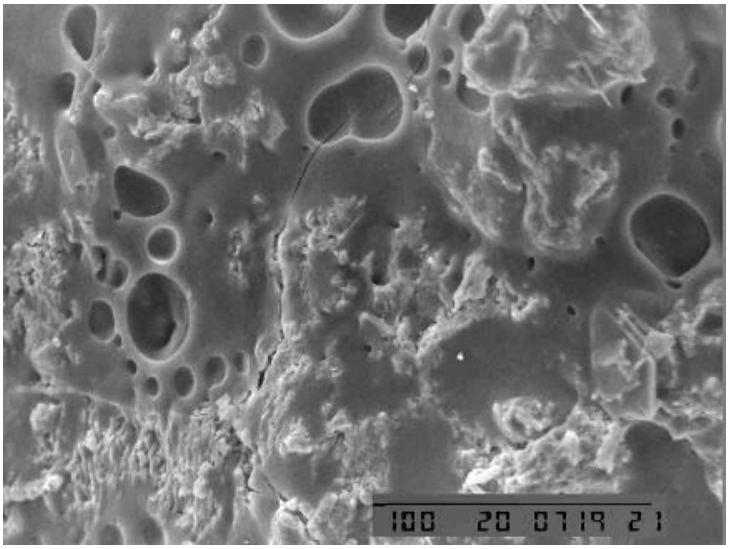

Aplikasi gondorukem $10 \%$

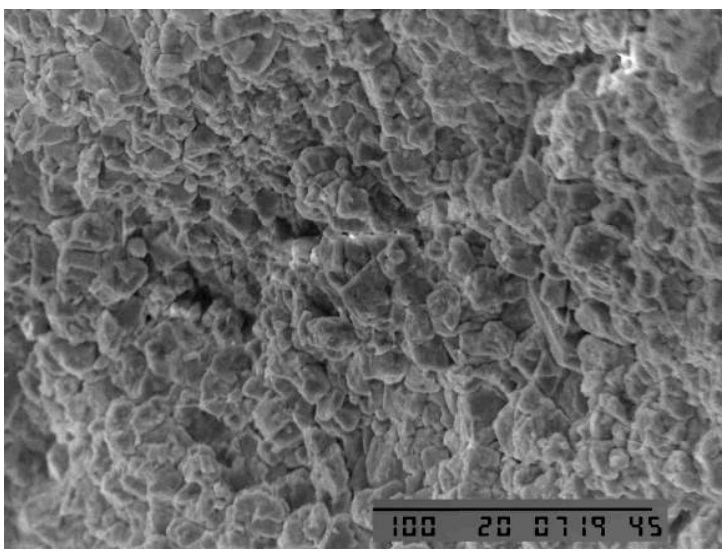

Aplikasi gelatin 5\%

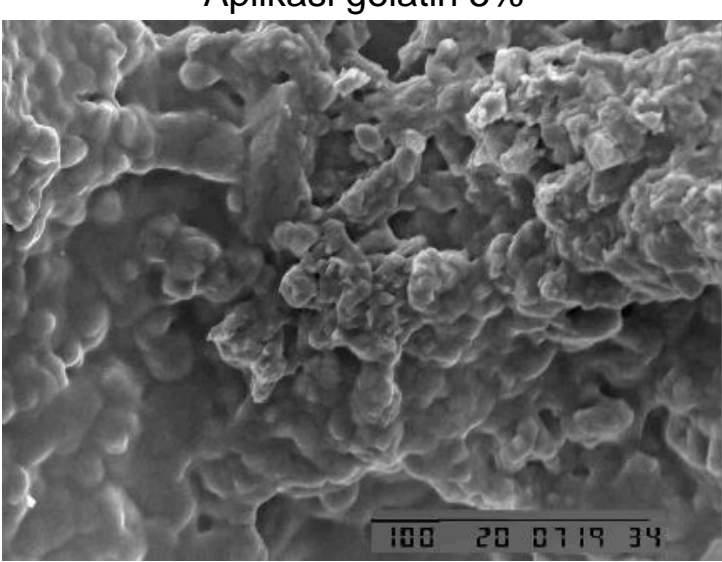

Aplikasi gelatin $15 \%$

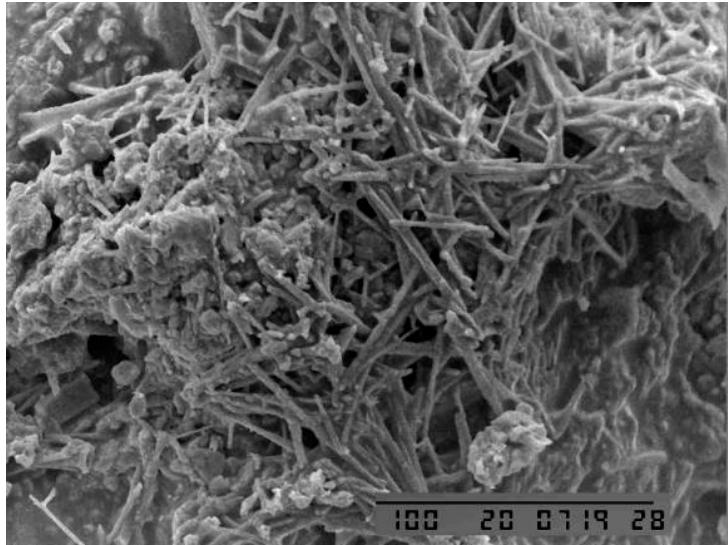

Aplikasi gondorukem $15 \%$

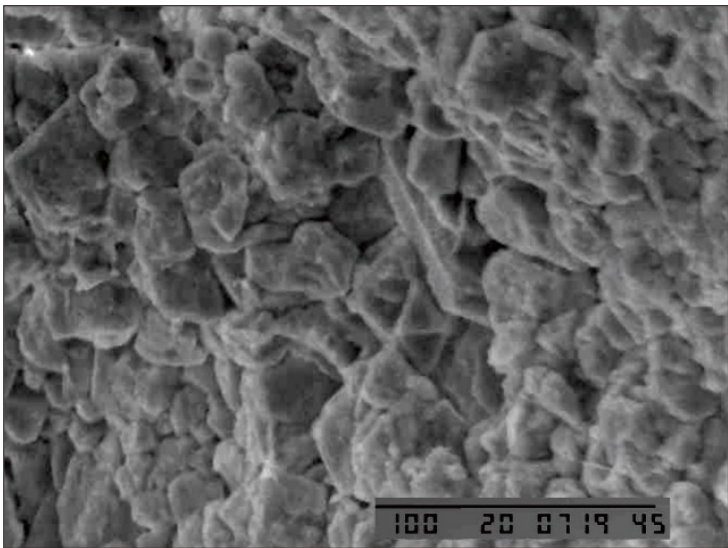

Aplikasi gelatin $10 \%$

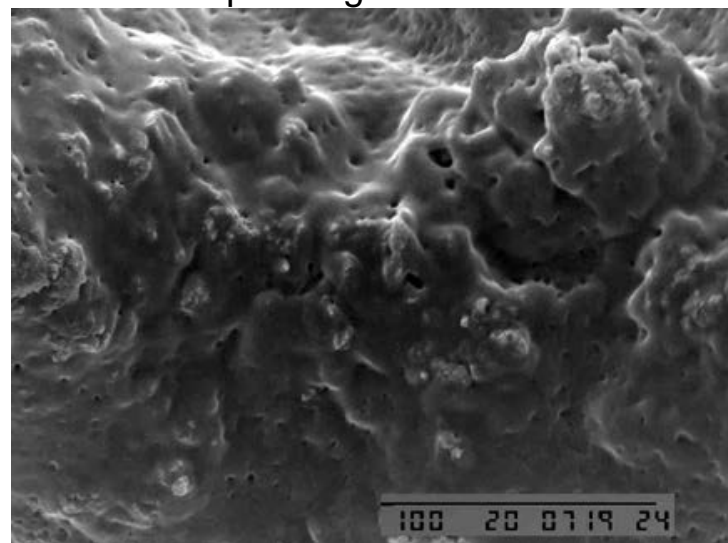

Aplikasi Paraloid B72 4\%

Hasil analisis SEM menunjukkan adanya perubahan kenampakan permukaan fosil setelah diberi perlakuan dengan konsolidan. Fosil rapuh yang tidak diberi perlakuan dengan bahan konsolidan cenderung terlihat lebih banyak memiliki pori-pori. Pada perlakuan dengan bahan konsolidan gondorukem, gelatin dan paraloid B72 terlihat poripori fosil tertutup oleh bahan konsolidan. Hal ini menunjukkan bahan konsolidan gondorukem, gelatin dan paraloid B72 dapat mengisi pori-pori fosil yang rapuh dan 
mengikat material fosil. Pada penggunaan bahan konsolidan gondorukem $15 \%$ terlihat adanya struktur seperti tumpukan jarum. Hal ini menunjukkan bahwa pada penggunaan bahan konsolidan gondorukem 15\% material gondorukem belum terlarut sempurna sehingga membentuk struktur seperti tumpukan jarum ketika diaplikasikan pada fosil yang rapuh.

\section{Uji kekerasan}

Untuk pengujian kekerasan dilakukan dengan alat Ultrasonic Hardness Tester dengan satuan kekerasan Brinell. Kelebihan Metode Brinell ini adalah sangat dianjurkan untuk material-material atau bahan-bahan uji yang bersifat heterogen (Wijayanto, 2017). Hasil pengujian kekerasan adalah sebagai berikut :

Tabel 2. Kekerasan fosil sebelum dan sesudah dilakukan konsolidasi

\begin{tabular}{llccc}
\hline No. & Konsolidan & \multicolumn{2}{c}{ Kekerasan (HB=Skala Kekerasan Brinell) } \\
\cline { 3 - 5 } & Gebelum perlakuan & $\begin{array}{c}\text { Setelah perlakuan } \\
\text { konsonsolidan }\end{array}$ & Kenaikan \\
\hline $\mathbf{1}$ & Gondorukem 5\% & 59 & 65 & 6 \\
$\mathbf{2}$ & Gondorukem 10\% & 57 & 68 & 11 \\
$\mathbf{3}$ & Gondorukem 15\% & 52 & 65 & 13 \\
$\mathbf{4}$ & Gelatin 5 \% & 58 & 60 & 2 \\
$\mathbf{5}$ & Gelatin 10\% & 48 & 56 & 8 \\
\hline $\mathbf{6}$ & Gelatin 15\% & 55 & 70 & 15 \\
$\mathbf{7}$ & Paraloid B72 4\% & 48 & 56 & 8 \\
\hline
\end{tabular}

Hasil pengujian kekerasan menunjukkan pengaplikasian bahan konsolidan gondorukem, gelatin dan paraloid B72 pada fosil yang rapuh dapat meningkatkan kekerasan fosil. Pada pengaplikasian bahan konsolidan gondorukem dan gelatin, peningkatan kekerasan fosil berbanding lurus dengan konsentrasi bahan konsolidan. Semakin tinggi konsentrasi bahan konsolidan semakin besar kenaikan kekerasan fosil.

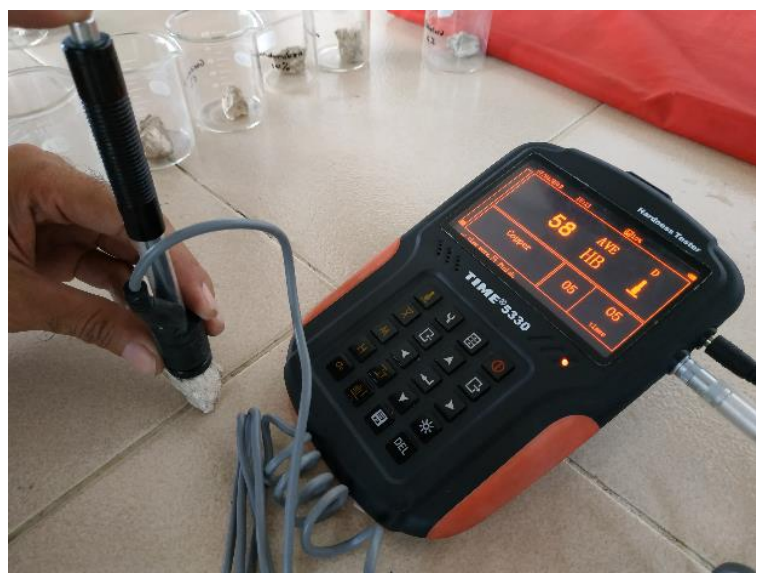

Gambar 8. Pengujian kekerasan spesimen uji menggunakan Ultrasonic Hardness Tester 


\section{Uji kuat tekan}

Uji kuat tekan dilakukan di Laboratorium Bahan Teknik, Departemen Teknik Mesin dan Industri, Fakultas Teknik UGM. Hasil pengujian kuat tekan adalah sebagai berikut :

Tabel 3. Kuat tekan fosil setelah dilakukan konsolidasi

\begin{tabular}{lcc}
\hline No. & Konsolidan & Kuat Tekan (N/cm2) \\
\hline $\mathbf{1}$ & Gondorukem 5\% & 22,10 \\
$\mathbf{2}$ & Gondorukem 10\% & 24,35 \\
$\mathbf{3}$ & Gondorukem 15\% & 97,51 \\
$\mathbf{4}$ & Gelatin 5 \% & 423,02 \\
$\mathbf{5}$ & Gelatin 10\% & 572,75 \\
$\mathbf{6}$ & Gelatin 15\% & 643,14 \\
$\mathbf{7}$ & Paraloid B72 4\% & 106,81 \\
\hline
\end{tabular}

Hasil pengujian kuat tekan menunjukkan pengaplikasian bahan konsolidan gondorukem, gelatin dan paraloid B72 pada fosil yang rapuh dapat meningkatkan kuat tekan fosil. Hal ini dikarenakan spesimen uji awalnya berupa bubukan dan setelah diberi perlakuan dengan bahan konsolidan memiliki kuat tekan yang bervariasi. Pada pengaplikasian bahan konsolidan gondorukem dan gelatin, nilai kuat tekan fosil berbanding lurus dengan konsentrasi bahan konsolidan. Semakin tinggi konsentrasi bahan konsolidan semakin besar nilai kuat tekan-nya. Penggunaan gelatin 5\%, 10\% dan $15 \%$ untuk konsolidasi fosil menghasilkan nilai kuat tekan yang lebih tinggi dari paraloid B72 4\%. Sedangkan penggunaan gondorukem 5\%, 10\% dan 15\% untuk konsolidasi fosil menghasilkan nilai kuat tekan yang lebih rendah dari paraloid B72 4\%.

\section{Uji tetesan air (water drop absorbtion test)}

Uji tetesan air dilakukan untuk melihat apakah spesimen uji yang telah dikonsolidasi dapat menyerap air atau tidak, sehingga akan terlihat apakah pori-pori permukaan sampel uji dalam kondisi terbuka atau tertutup setelah dilakukan konsolidasi.

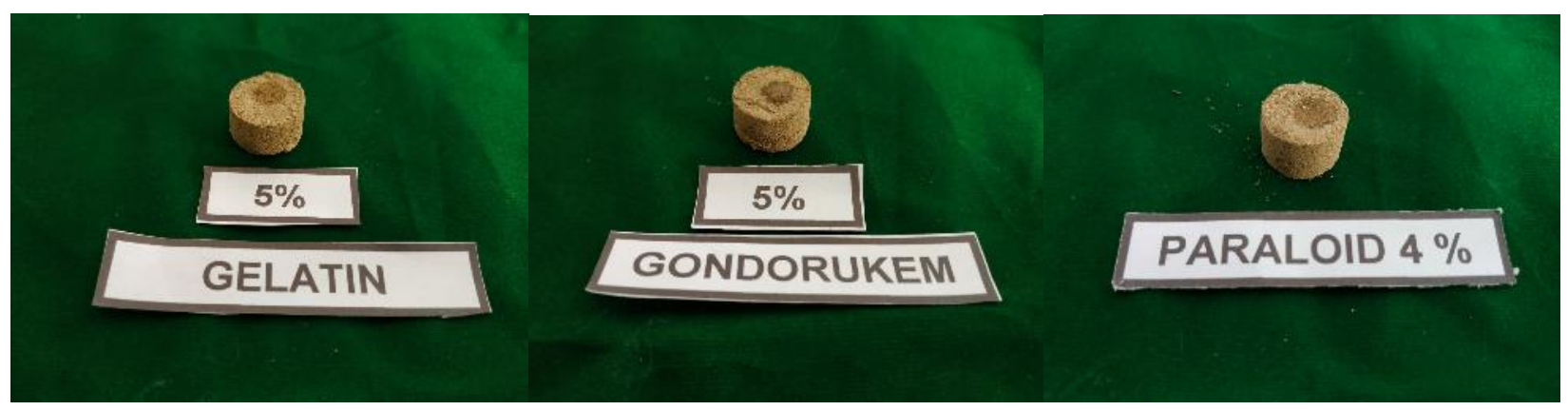

Gambar 9. Uji tetesan air pada spesimen uji

Tabel 4. Hasil uji tetesan air pada sampel fosil

\begin{tabular}{ccccc}
\hline & No. & Konsolidan & $\begin{array}{c}\text { Hasil } \\
\text { Pengujian }\end{array}$ & Waktu \\
\hline 1 & & Gondorukem $5 \%$ & Tidak & -
\end{tabular}


Haldoko dkk, Konsolidasi Fosil Menggunakan Resin Alam

\begin{tabular}{|c|c|c|c|c|c|}
\hline & & & \multicolumn{3}{|c|}{ meresap } \\
\hline 2 & & & Gondorukem 10\% & $\begin{array}{c}\text { Tidak } \\
\text { meresap }\end{array}$ & - \\
\hline 3 & & & Gondorukem 15\% & $\begin{array}{c}\text { Tidak } \\
\text { meresap }\end{array}$ & - \\
\hline 4 & & & Gelatin 5 \% & Meresap & 1 detik \\
\hline 5 & Gelatin $10 \%$ & Meresap & \multicolumn{3}{|c|}{9 detik } \\
\hline 6 & Gelatin 15 \% & Meresap & \multicolumn{3}{|c|}{3 menit 49 detik } \\
\hline 7 & Paraloid B72 4\% & Meresap & \multicolumn{3}{|c|}{3 detik } \\
\hline
\end{tabular}

Dari hasil pengujian terlihat bahwa pengaplikasian bahan konsolidan gondorukem $5 \%, 10 \%$ dan $15 \%$ membuat air tidak dapat masuk ke dalam spesimen uji. Sedangkan pada pengaplikasian bahan konsolidan gelatin 5\%, 10\% dan 15\% dan paraloid B72 4\% air dapat meresap ke dalam pori-pori spesimen uji. Semakin tinggi konsentrasi gelatin semakin lama pula waktu air untuk meresap.

\section{Uji FTIR}

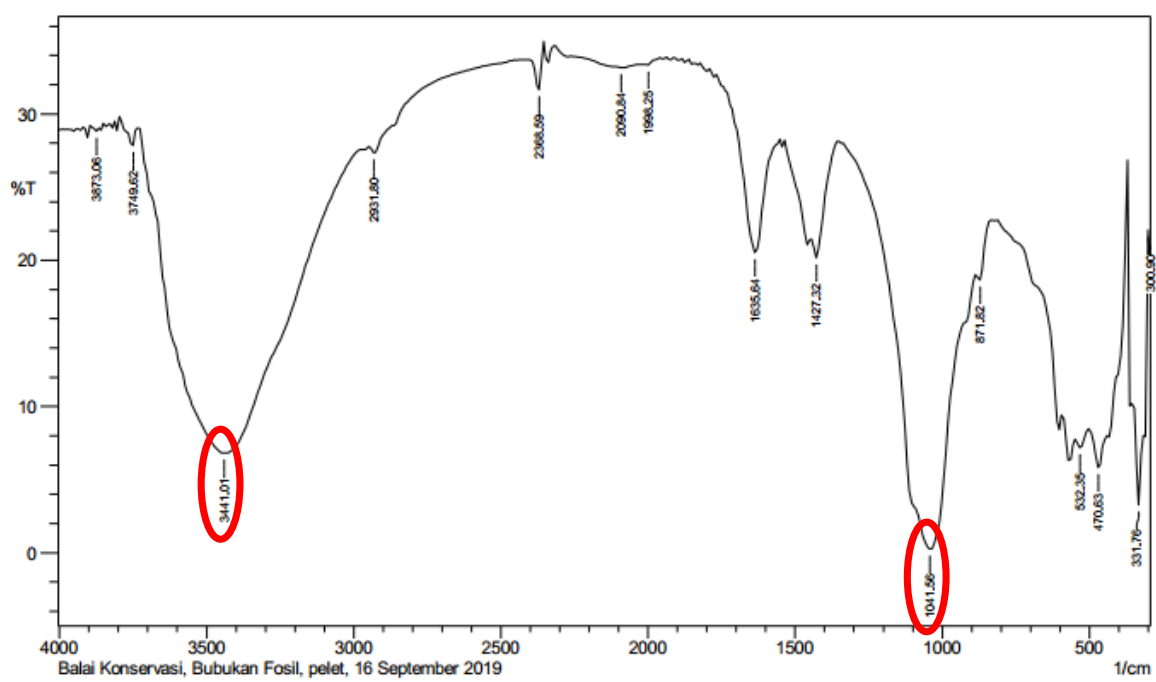

- Spektrum bubukan fosil yang dikonsolidasi dengan gondorukem, gelatin, dan paraloid B72 dianalisis agar dapat dibandingkan dengan spektrum bubukan fosil yang belum dikonsolidasi. Spektrum bubukan fosil yang dikonsolidasi dengan gondorukem,

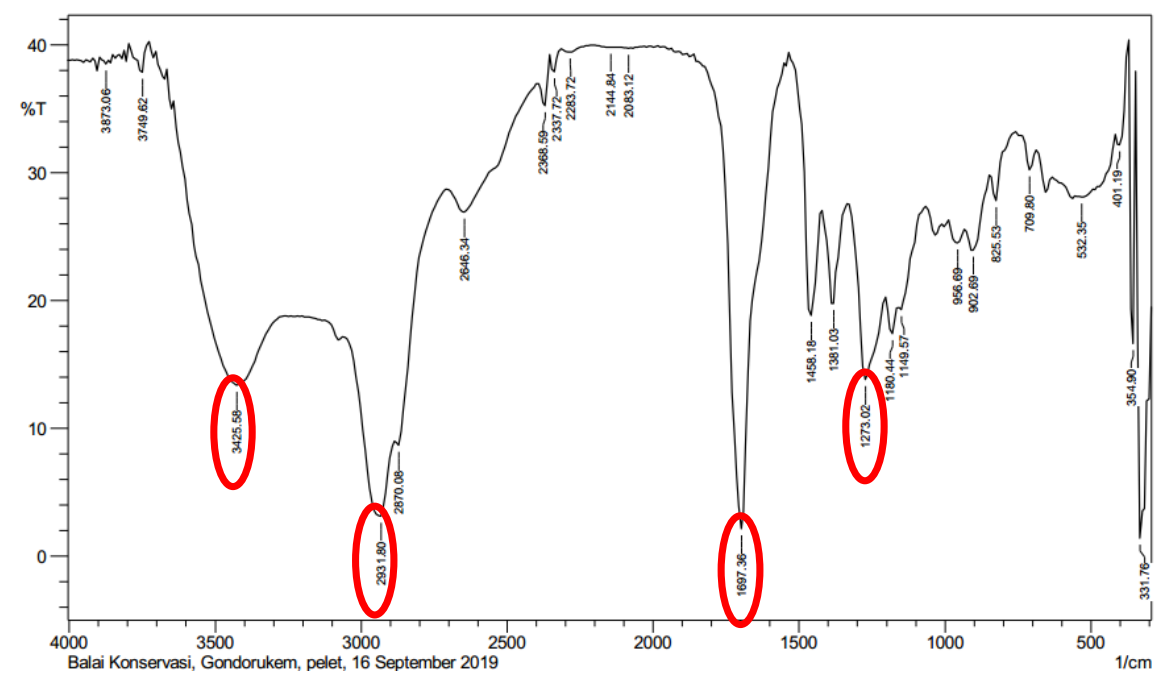




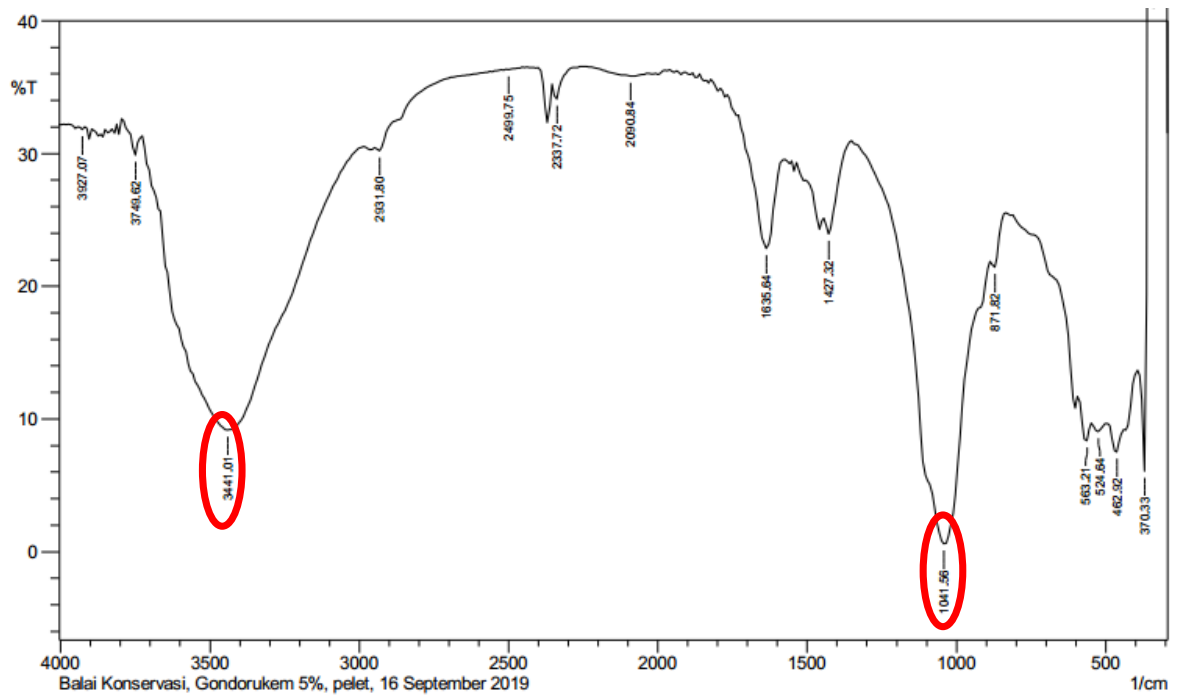

gelatin dan paraloid B72 memiliki pola absorban yang mirip dengan bubukan fosil yang belum dikonsolidasi yaitu spektrum 3441,01 menunjukkan ikatan O-H stretching (adanya $\mathrm{H} 2 \mathrm{O}$ atau air) dan spektrum 1041,56 menunjukkan ikatan SiOCH3 (strong) menandakan adanya silika.

- Spektrum bubukan fosil yang dikonsolidasi dengan gondorukem 5\%, 10\% dan
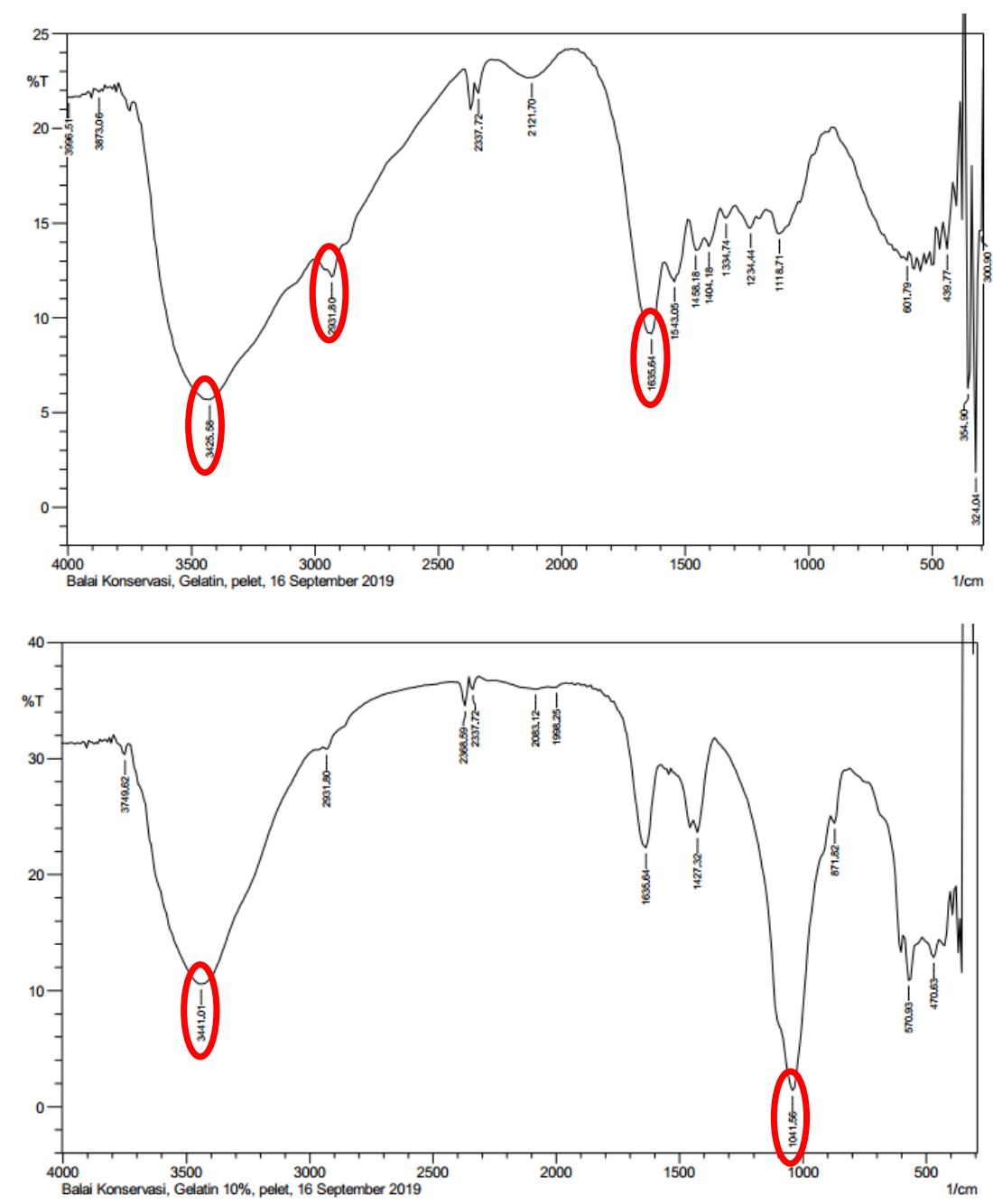
15\% memiliki pola absorban yang berbeda dengan spektrum gondorukem. Gondorukem memiliki spektrum 3425,58 menunjukkan ikatan O-H stretching, spektrum 2931,80 ikatan C-H stretching, spektrum 1697,36 ikatan C=O stretching (amida 1) dan spektrum 1273,02 ikatan C-N stretching (amine aromatic). Sedangkan bubukan fosil yang dikonsolidasi dengan gondorukem 5\%, 10\%, 15\% memiliki spektrum yang sama dengan bubukan fosil yang belum dikonsolidasi. Hal ini menunjukkan penggunaan gondorukem 5\%, 10\%, 15\% untuk konsolidasi fosil tidak merubah komposisi fosil.

- Spektrum bubukan fosil yang dikonsolidasi dengan gelatin 5\%, 10\% dan 15\% memiliki pola absorban yang berbeda dengan spektrum gelatin. Gelatin memiliki spektrum 3425,58 menunjukkan ikatan O-H stretching, spektrum 2931,80 ikatan C-H stretching, spektrum 1635,64 ikatan $\mathrm{C}=\mathrm{C}$ stretching. Sedangkan bubukan fosil yang dikonsolidasi dengan gelatin 5\%, 10\%, 15\% memiliki spektrum yang sama dengan bubukan fosil yang belum dikonsolidasi. Hal ini menunjukkan penggunaan gelatin 5\%, 10\%, 15\% untuk konsolidasi fosil tidak merubah komposisi fosil.
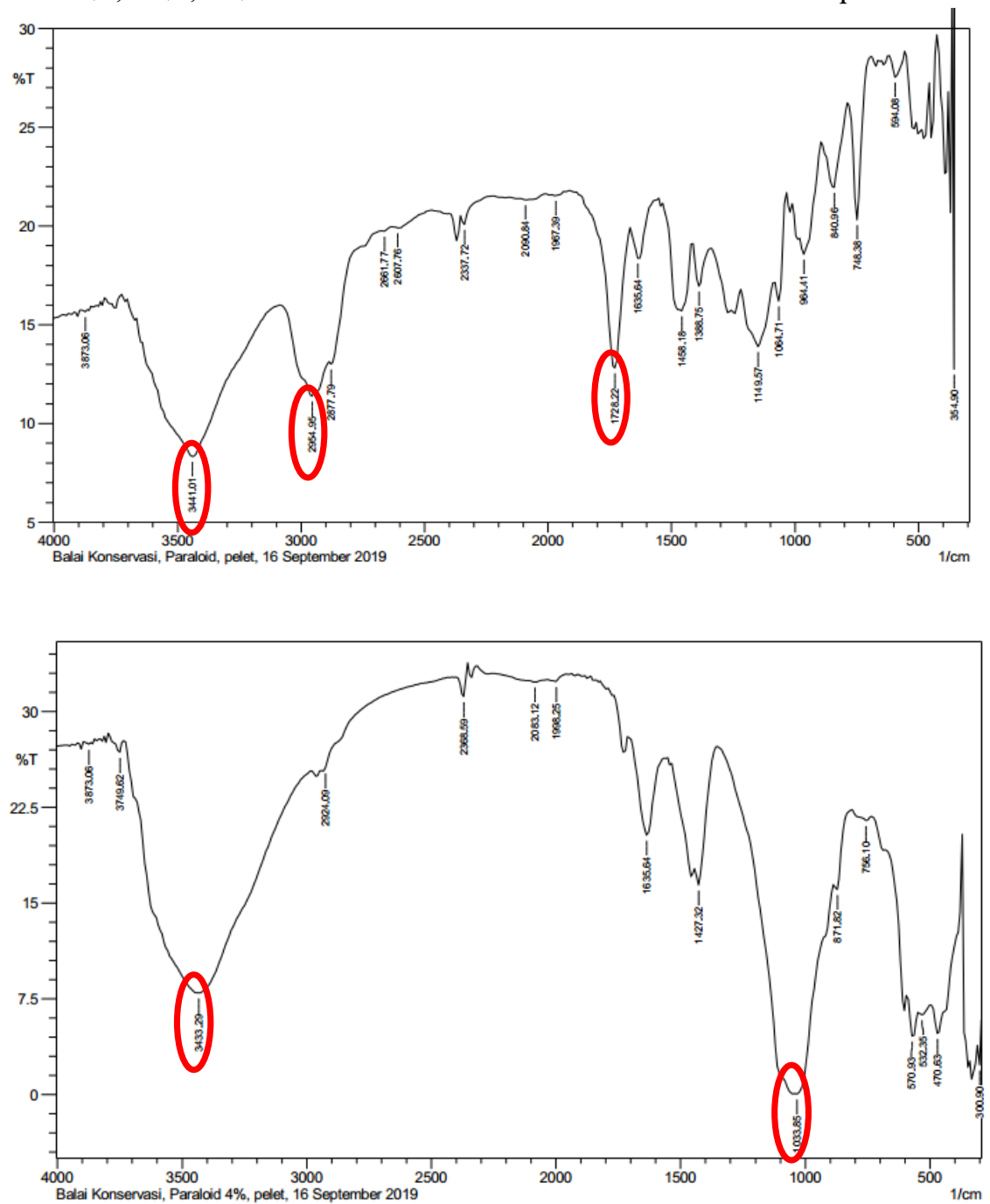

- Spektrum bubukan fosil yang dikonsolidasi dengan paraloid B72 4\% memiliki pola absorban yang berbeda dengan spektrum paraloid B72. Paraloid B72 memiliki spektrum spektrum 3441,01 menunjukkan ikatan O-H stretching, spektrum 
2954,95 ikatan C-H stretching, spektrum 1728,22 ikatan C=O stretching. Sedangkan bubukan fosil yang dikonsolidasi dengan paraloid B72 4\% memiliki spektrum yang sama dengan bubukan fosil yang belum dikonsolidasi. Hal ini menunjukkan penggunaan paraloid B72 4\% untuk konsolidasi fosil tidak merubah komposisi fosil.

\section{Uji daya tahan (aging test)}

Uji daya tahan (aging test) dilakukan untuk melihat daya tahan sampel setelah melewati kondisi yang diekstrimkan dari kondisi penyimpanan biasanya. Uji daya tahan dilakukan dengan 2 perlakuan yaitu pada kondisi kelembaban 90\% dalam inkubator dan temperatur $50^{\circ} \mathrm{C}$ dalam oven. Setiap perlakuan dilakukan selama 24 jam dengan total selama 10 siklus.

Tabel 5. Hasil uji daya tahan (aging test) sampel fosil

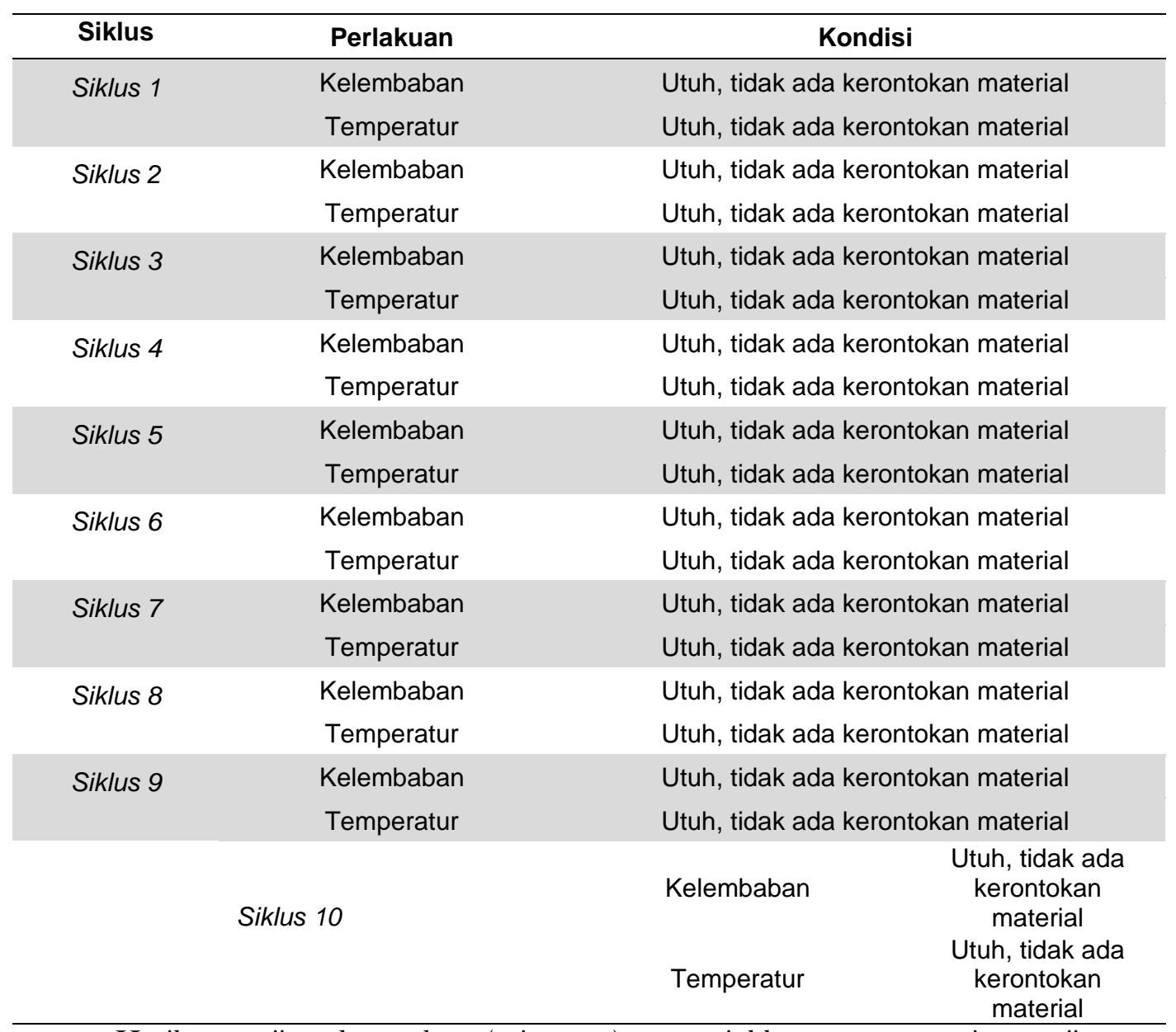

Hasil pengujian daya tahan (aging test) menunjukkan semua spesimen uji yang dikonsolidasi dengan gondorukem, gelatin, maupun paraloid B72 tahan terhadap kondisi temperatur dan kelembaban udara yang ekstrim. Hal ini dapat dilihat dari kondisi fosil yang utuh yang diindikasikan dengan tidak adanya kerontokan material. Ini menandakan ikatan antar butiran material bubukan fosil yang telah dikonsolidasi masih kuat setelah melewati aging test. 


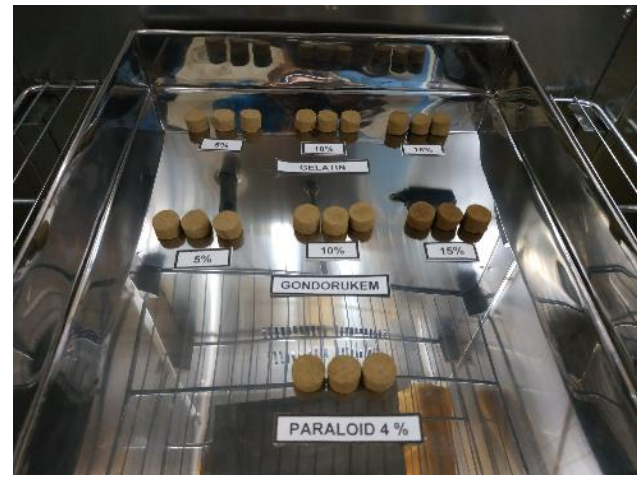

Gambar 10. Pengujian daya tahan (aging test) pada inkubator

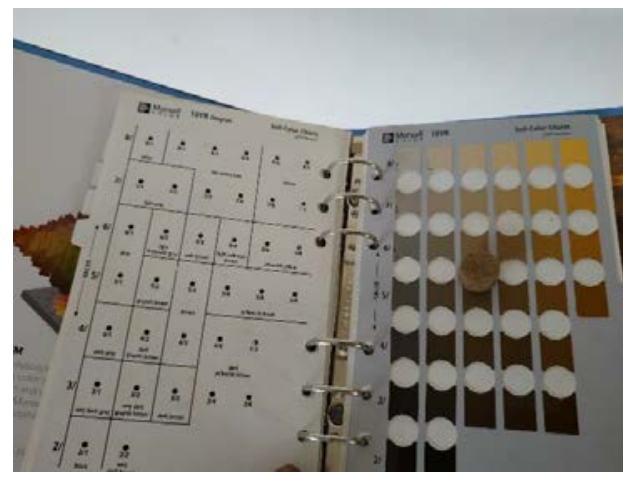

Gambar 11. Pengamatan warna fosil dengan Munsell Soil Color Book

\section{Pengamatan warna}

Warna merupakan komponen yang sangat penting pada cagar budaya. Penggunaan bahan konservan diharapkan tidak sampai merubah warna material cagar budaya. Karena itu pengamatan warna pada fosil yang telah dikonsolidasi perlu dilakukan untuk melihat ada atau tidaknya perubahan warna jika dibandingkan dengan fosil yang belum dikonsolidasi. Pengamatan warna ini dilakukan dengan alat bantu Munsell Soil Color Book. Hasilnya adalah sebagai berikut :

Tabel 6. Warna fosil sebelum dan sesudah dilakukan konsolidasi

\begin{tabular}{|c|c|c|c|}
\hline \multirow[b]{2}{*}{ No. } & \multirow[b]{2}{*}{ Konsolidan } & \multicolumn{2}{|c|}{ Warna fosil } \\
\hline & & $\begin{array}{c}\text { Sebelum perlakuan } \\
\text { konsolidan }\end{array}$ & Setelah perlakuan konsolidan \\
\hline 1 & Gondorukem 5\% & 6/3 10YR (pale brown) & 6/3 10YR (pale brown) \\
\hline 2 & Gondorukem 10\% & 6/3 10YR (pale brown) & 6/3 10YR (pale brown) \\
\hline 3 & Gondorukem 15\% & 6/3 10YR (pale brown) & 5/4 10YR (yellow brown) \\
\hline 4 & Gelatin $5 \%$ & 6/3 10YR (pale brown) & 6/3 10YR (pale brown) \\
\hline 5 & Gelatin $10 \%$ & 6/3 10YR (pale brown) & 6/3 10YR (pale brown) \\
\hline 6 & Gelatin $15 \%$ & 6/3 10YR (pale brown) & 6/3 10YR (pale brown) \\
\hline 7 & Paraloid B72 4\% & 6/3 10YR (pale brown) & 6/3 10YR (pale brown) \\
\hline
\end{tabular}

Hasil pengamatan warna menunjukkan perubahan warna fosil hanya terjadi pada spesimen yang dikonsolidasi dengan gondorukem 15\%. Sedangkan pada spesimen fosil yang dikonsolidasi dengan penggunaan gondorukem 5\% dan 10\%, gelatin 5\%, 10\% dan $15 \%$, serta paraloid B72 4\% tidak terjadi perubahan warna. Hal ini menandakan secara warna, bahan konsolidan tersebut layak untuk digunakan untuk konsolidasi fosil.

\section{Pengamatan pertumbuhan jamur}

Bahan yang diuji untuk konsolidasi fosil salah satunya adalah gelatin yang berasal dari protein. Penggunaan bahan yang organik yang berbasis protein bisa saja ditumbuhi jamur. Karena itu dilakukan pengamatan visual pada spesimen fosil yang telah dikonsolidasi untuk melihat ada/tidaknya pertumbuhan jamur pada permukaan fosil 
dengan bantuan mikroskop. Pengamatan dilakukan spesimen uji sebelum dilakukan konsolidasi dan setelah dilakukan konsolidasi selama 3 bulan.

Tabel 7. Kenampakan visual permukaan fosil sebelum dan sesudah dikonsolidasi

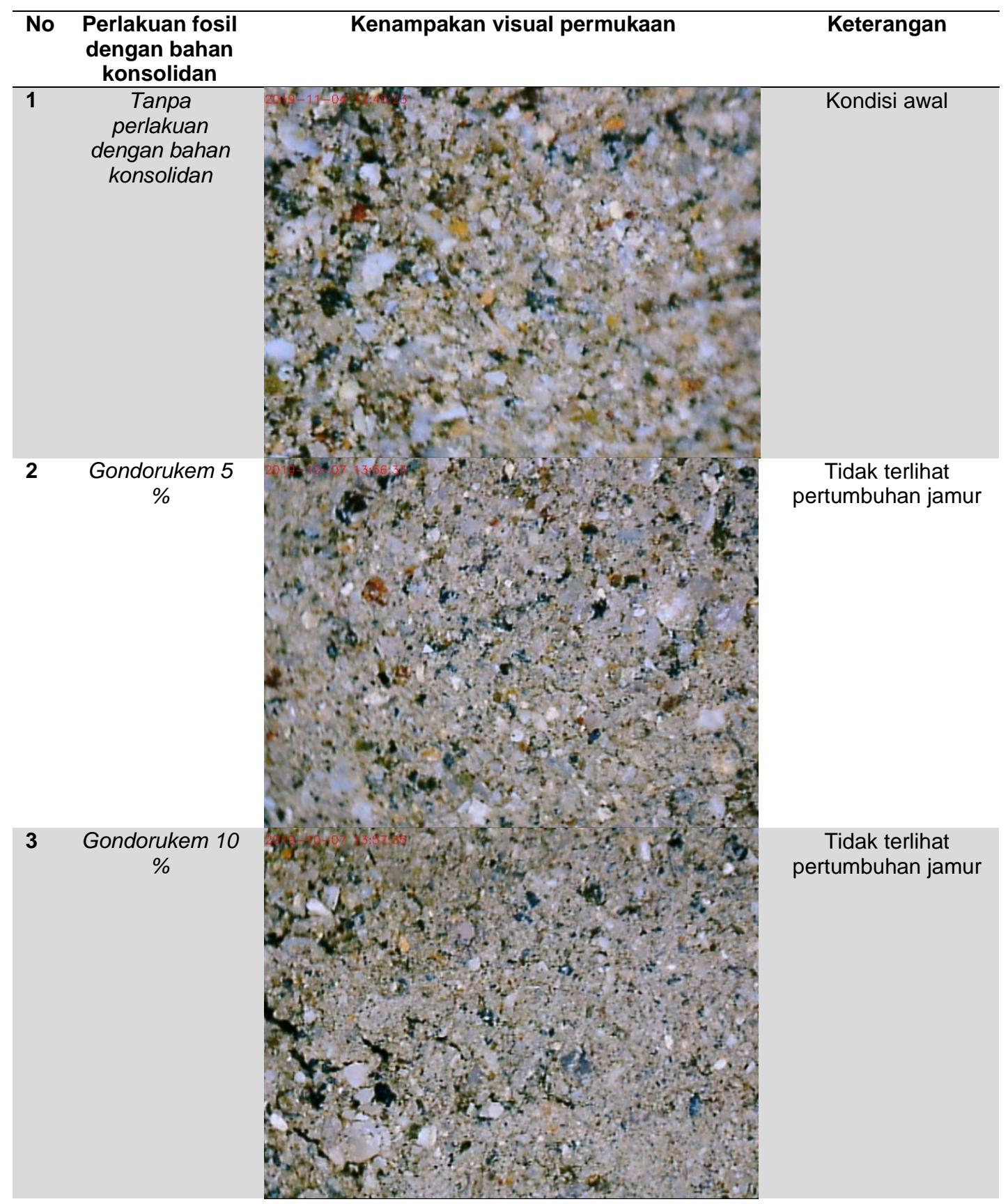


Haldoko dkk, Konsolidasi Fosil Menggunakan Resin Alam

Gondorukem 15

$\%$

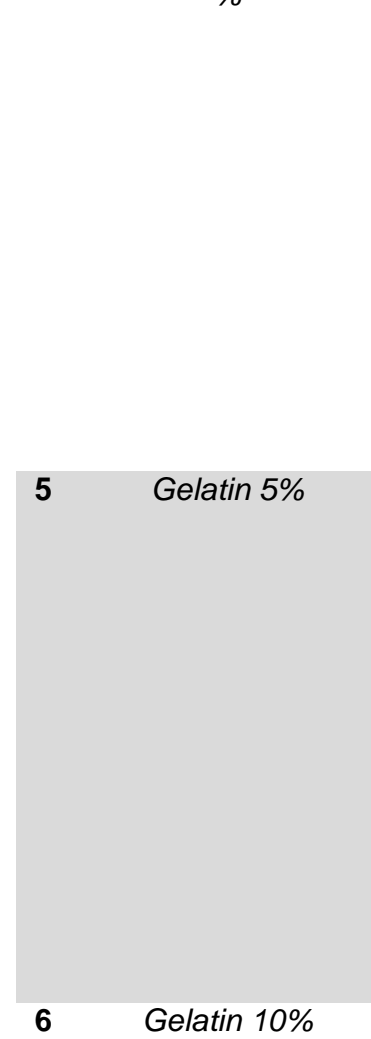

7 Gelatin 15\%

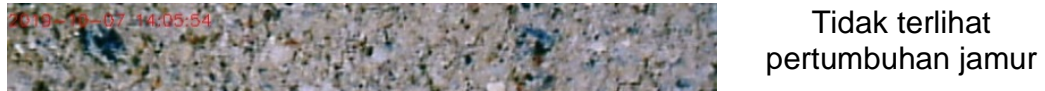

pertumbuhan jamur
Tidak terlihat pertumbuhan jamur
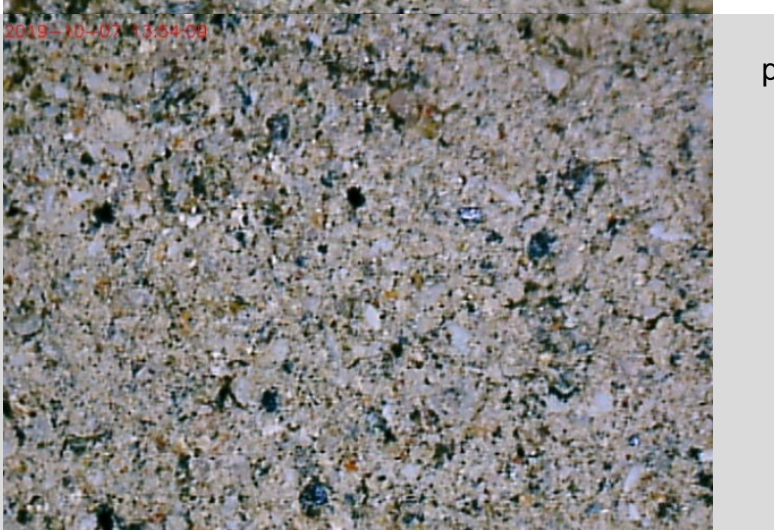

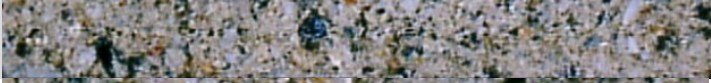

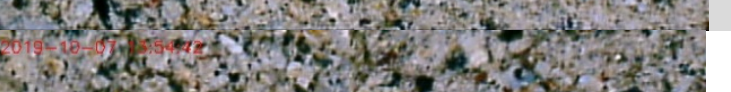

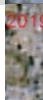
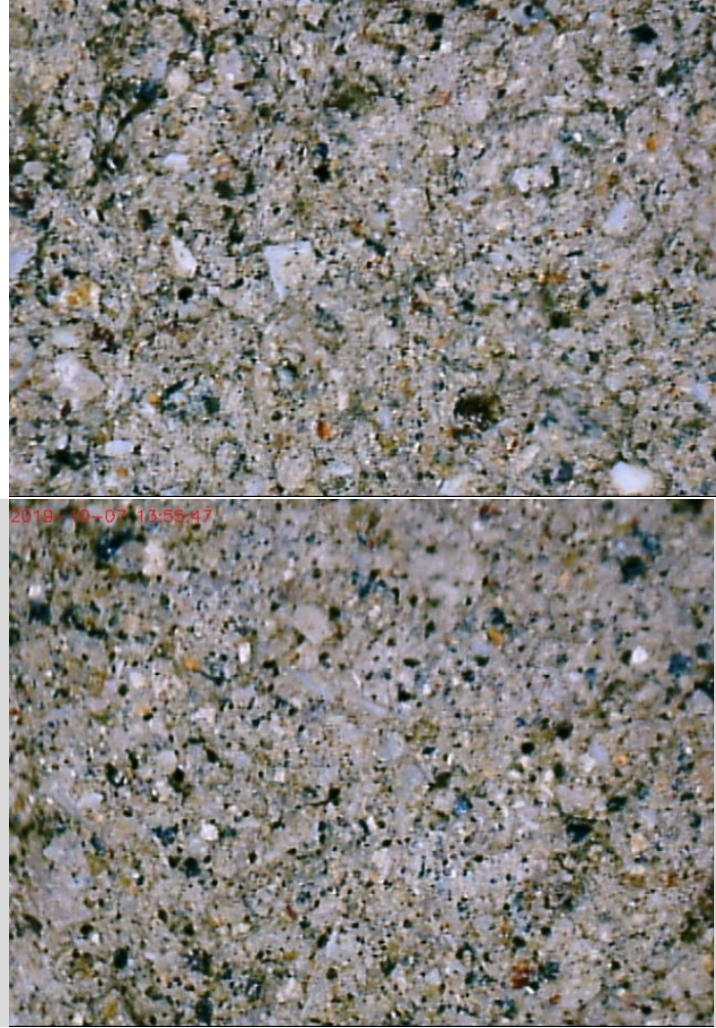

Tidak terlihat pertumbuhan jamur 


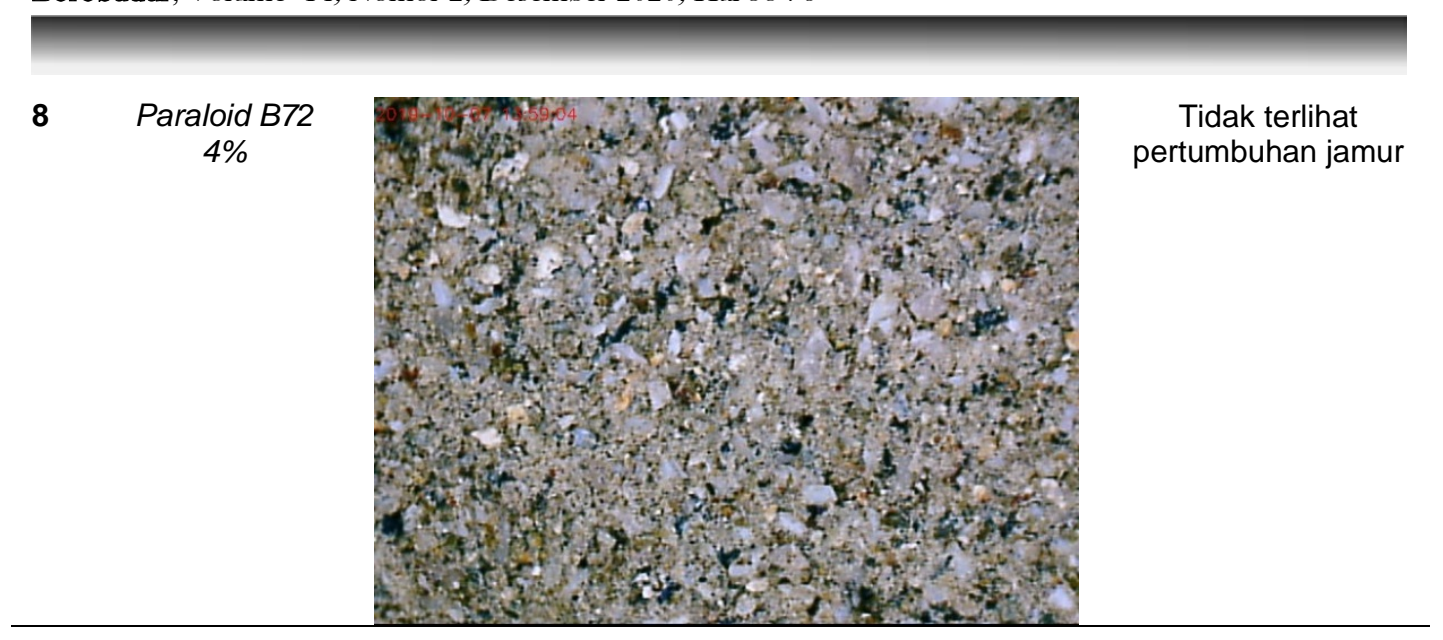

Hasil pengamatan menujukkan pada seluruh spesimen uji yang dikonsolidasi baik dengan gelatin, gondorukem dan paraloid B72 tidak ada yang ditumbuhi jamur pada permukaannya. Hal ini menunjukkan bahan-bahan yang diuji relatif aman dari pertumbuhan jamur. Penggunaan gelatin yang berasal dari protein untuk konsolidasi fosil juga tidak ditumbuhi jamur karena hasil konsolidasi sudah benar-benar kering. Meskipun demikian larutan gelatin tidak boleh dibiarkan lebih dari 2 hari, karena ketika dalam bentuk cair akan dapat ditumbuhi jamur. Oleh karena itu pembuatan larutan gelatin dilakukan sesaat sebelum digunakan untuk konsolidasi fosil

\section{KESIMPULAN}

Dari seluruh pengujian yang telah dilakukan didapatkan hasil bahwa penggunaan gelatin 5\%, 10\% dan 15\% dapat menjadi alternatif pengganti paraloid B72 sebagai bahan konsolidasi fosil. Gelatin 5\% merupakan konsentrasi yang paling optimum untuk konsolidasi fosil karena penggunaan bahan akan lebih efisien. Bahan ini dapat mengisi pori-pori fosil dan meningkatkan kekerasan fosil. Nilai kuat tekan yang dihasilkan pada spesimen uji mencapai 423,02 N/cm2 lebih tinggi dari paraloid B72 4\% yang hanya 106,81 $\mathrm{N} / \mathrm{cm} 2$. Penggunaan gelatin juga tidak merubah komposisi fosil dan memiliki daya tahan pada kondisi penyimpanan yang ekstrim. Penggunaan gelatin juga tidak merubah warna fosil dan aman dari pertumbuhan jamur ketika diaplikasikan untuk konsolidasi fosil. 


\section{DAFTAR PUSTAKA}

Abercrombie, M., 1990, Kamus Lengkap Biologi, Penerbit Erlangga, Jakarta.

Boer, E., Ella, A.B., 2000, Plant Resources of South East Asia, Backhuys Publishers.

Brown, Matthew A., John F. Kane, and William G. Parker, 2009, Methods in Fossil Preparation : Proceedings of the First Annual Fossil Preparation and Collections Symposium, Petrified Forest.

Getty R.,1975, Sisson and Grossman's the Anatomy of the Domestic Animal, W.B. Saunders Company, Philadelphia.

Rachmania, R.A., Fatimah N., Elok M., Ekstraksi Gelatin dari Tulang Ikan Tenggiri Melalui Proses Hidrolisis menggunakan Larutan Basa, Jurusan Farmasi Universitas Muhammadiyah Prof. Dr. Hamka, Jakarta.

Schellmann, N.C., 2007, Animal Glues: A Review of Their Key Properties Relevant to Conservation, Studies in Conservation, Researchgate.

Wijayanto, Bagas, 2017, Pengaruh Feeding pada Proses Surface Grinding terhadap Kekasaran dan Kekerasan Permukaan Baja EMS 45 Pasca Diquenching Menggunakan Air Dromus, Jurusan Teknik Mesin, Universitas Negeri Semarang. 